This document was prepared in conjunction with work accomplished under Contract No.

DE-AC09-76SR00001 with the U.S. Department of Energy.

\title{
DISCLAIMER
}

This report was prepared as an account of work sponsored by an agency of the United States Government. Neither the United States Government nor any agency thereof, nor any of their employees, makes any warranty, express or implied, or assumes any legal liability or responsibility for the accuracy, completeness, or usefulness of any information, apparatus, product or process disclosed, or represents that its use would not infringe privately owned rights. Reference herein to any specific commercial product, process or service by trade name, trademark, manufacturer, or otherwise does not necessarily constitute or imply its endorsement, recommendation, or favoring by the United States Government or any agency

thereof. The views and opinions of authors expressed herein do not necessarily state or reflect those of the United States Government or any agency thereof.

This report has been reproduced directly from the best available copy.

Available for sale to the public, in paper, from: U.S. Department of Commerce, National Technical Information Service, 5285 Port Royal Road, Springfield, VA 22161, phone: (800)

553-6847, fax: (703) 605-6900, email: orders@ntis.fedworld.gov online ordering: http://www.ntis.gov/ordering.htm

Available electronically at http://www.doe.gov/bridge

Available for a processing fee to U.S. Department of Energy and its contractors, in paper, from: U.S. Department of Energy, Office of Scientific and Technical Information, P.O. Box 62, Oak Ridge, TN 37831-0062, phone: (865 ) 576-8401, fax: (865) 576-5728, email: reports@ adonis.osti.gov 
TECHNICAL DIVISION

SAVANNAH RIVER LABORATORY

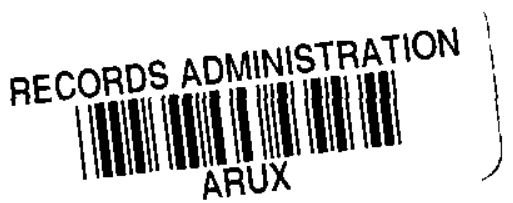

DPST $-86-694$
TO:
E. W. HOLTZSCHEITER, 773-A

FROM: D. G. KARRAKER, 773-A Uel
October 1, 1986
J. F. Ortaldo, 703-A
J. T. Buckner, 703-F
D. B. Moore, 703-F
J. V. Odum, 703-F
C. W. Jenkins, 221-F
D. F. Chostner, 221-F
R. A. L. Eubanks, 221-F
J. T. Lowe, 773-A
R. J. Guschl, 773-A
D. A. Orth, 773-A
S. T. Augsburger, 773-A
A. L. Blancett, 773-A
D. L. Holt, 773-A
T. C. Hsu, 773-A
SRL Records (4)

\section{RELATIVE REACTION RATES OF SULFAMIC ACID AND HYDROXYLAMINE WITH NITRIC ACID}

\section{INTRODUCTION}

Sulfamic acid ( $\mathrm{HSO}_{3} \mathrm{NH}_{2}$, "HSA") and hydroxylamine nitrate $\left(\mathrm{NH}_{2} \mathrm{OH} \cdot \mathrm{HNO}_{3}\right.$, "HAN") al'e used in SRP solvent extraçtion ąnd ion exchange processes to prevent the oxidation of $\mathrm{Fe}^{2+}, \mathrm{Pu}^{3+}$ and $\mathrm{Np}^{4+}$ by nitric acid. In the abşence of njtrous acid (HNO,), nitric acid oxidation of $\mathrm{Fe}^{2+}, \mathrm{Pu}^{3+}$, or $\mathrm{Np}^{47}$ is very slow, But when HNo is present to provide a kinetic path, the reaction is qujte rapia. Since $\mathrm{HNO}_{2}$ is a product of $\mathrm{HNO}_{3}$ oxidation of $\mathrm{Pu}$ or $\mathrm{Np}^{3}$, the reaction becomes autocatalytic. The effectiveness of holding reductants depends on their rate of reaction with the radiolytically or chemically generated $\mathrm{HNO}_{2}$. The report describes a study of comparative reaction rates where the reductant is in excess, as in the $1 \mathrm{~B}$ bank in the Purex process. The results of this work apply to planned plant tests to partially substitute HAN for the ferrous sulfamate reductant in the Purex $1 \mathrm{~B}$ bank. 


\section{SUMMARY}

The comparative reaction rates of $\mathrm{HSA}$ and $\mathrm{NH}_{2} \mathrm{OH}$ with nitrous acid were measured at room temperature over the acid range 0.3 to $3.5 \mathrm{M}$ $\mathrm{HNO}_{3}$ and the ratio of the reaction rate constants found to be $\mathrm{k}\left(\mathrm{NH}_{2} \mathrm{OH}\right) / \mathrm{k}(\mathrm{HSA})=0.056+0.082\left[\mathrm{H}^{+}\right]$. Application of these results to plant processes allows a calculation of relative amount of reductant to achieve the same rate of nitrite destruction. For example, with a $1 \mathrm{~B}$ bank acidity of $1.5 \mathrm{M}$, a reduction of $0.02 \mathrm{M}$ HSA requires a calculated $0.11 \mathrm{M}$ HAN to maintain the equivalent nitrite destruction rate. The solid waste saving for the reduction of ferrous sulfamate in the Purex $1 \mathrm{BX}$ is calculated to be $\$ 600 \mathrm{M} / 1000$ MTU for each $0.01 M$ reduction.

\section{BACKGROUND}

The reactions of $\mathrm{HNO}_{2}$ with $\mathrm{HSA}$ and $\mathrm{NH}_{2} \mathrm{OH}$ in acid solution proceed through intermediate ${ }^{2}$ species to yield ${ }^{2}$ only gaseous products. The reactions are extremely rapid and, in a superficial sense, are complete during the time of mixing. These reactions have been studied kinetically by stopped flow techniques and under conditions where the reactions are slow enough for conventional kinetic methods (low concentration; low acidity, $0^{\circ} \mathrm{C}$ ). In this study, the reductants were studied in competition with each other and the relative rates determined from analyses of the gaseous products.

This method is based on the different products produced by the reaction between $\mathrm{HNO}_{2}$ and the different reductants. The net

$$
\begin{aligned}
& \mathrm{HSO}_{3} \mathrm{NH}_{2}+\mathrm{HNO}_{2} \longrightarrow \mathrm{SO}_{4}+2 \mathrm{H}^{+}+\mathrm{N}_{2}+\mathrm{H}_{2} \mathrm{O} \\
& \mathrm{NH}_{3} \mathrm{OH}^{+}+\mathrm{HNO}_{2} \longrightarrow \mathrm{N}_{2} \mathrm{O}+2 \mathrm{H}_{2} \mathrm{O}+\mathrm{H}^{+}
\end{aligned}
$$

From equations 1 and 2 , the reaction of HSA with HNO produces $\mathrm{N}_{2}$ ' and the reaction of $\mathrm{NH}_{2} \mathrm{OH}$ with $\mathrm{HNO}_{2}$ produces $\mathrm{N}_{2} \mathrm{O}$. Thus, the relative reaction rates of two reductants in competition for $\mathrm{HNO}_{2}$ can be determined from the ratio of $\mathrm{N}_{2}$ to $\mathrm{N}_{2} \mathrm{O}$.

\section{EXPERIMENTAL}

\section{Reagents} $\mathrm{NaNO}_{2}$ and $\mathrm{HSO}_{3} \mathrm{NH}_{2}$ were c.p. grade; $\mathrm{NH}_{2} \mathrm{OH} \cdot \mathrm{HNO}_{3}$ was obtained from
SRP as a $1.8 \mathrm{M}^{3}$ solution. 


\section{Apparatus}

The reaction vessel was a standard $100 \mathrm{~mL}$ flask fitted with a small side neck. The principal neck of the flask was connected through Tygon tubing to a gas sample tube and then a water filled flask. Evolution of the gas from a reaction displaces the gas in the system and forces water from the water flask for measurement of the total gas evolved.

\section{Procedure}

A solution of $\mathrm{HSA}$ and $\mathrm{NH}_{2} \mathrm{OH} \cdot \mathrm{HNO}_{3}$ in nitric acid (total volume,

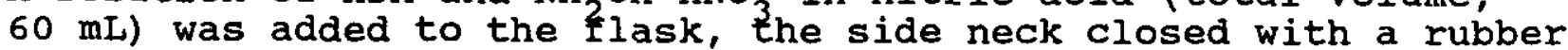
septum and the gas sample tube connected to the reaction flask. The reaction flask and gas sample tube were flushed for about 15 minutes with argon introduced via a hypodermic needle through the rubber septum. After flushing, the water filled flask was connected to the system and the reaction initiated by discharging $6 \mathrm{~mm}$ of $\mathrm{NaNO}_{2}$ ( $1 \mathrm{~mL}$ of $6 \mathrm{M} \mathrm{NaNO}_{2}$ ) by hypodermic needle through the rubber septum. The volume of thater displaced was measured by a graduated cylinder, and the contents of the gas sample tube were analyzed by gas chromatography. The analytical method was tested with gas samples produced by reacting $\mathrm{NaN}_{3}$ with $\mathrm{HNO}_{2}$ and found to be within $8 \%$ of the theoretical ratio of $\mathrm{N}_{2} / \mathrm{N}_{2} \mathrm{O}=1^{2}$ all reactions were initiated at room temperature, $25 \pm 3^{\circ} \mathrm{C}$, but the heat released by the reaction raised the solution temperature to about $30^{\circ} \mathrm{C}$.

\section{RESULTS AND DISCUSSION}

Experiments on the relative reaction rates of $\mathrm{HSA}$ and $\mathrm{NH}_{2} \mathrm{OH} \cdot \mathrm{HNO}$ with $\mathrm{HNO}_{2}$ were studied over the acid range 0.3 to $3.5 \mathrm{M} \mathrm{H} \mathrm{HO}_{3}$ with (1) $0.27 \mathrm{M} \mathrm{NH}_{2} \mathrm{OH} \cdot \mathrm{HNO}_{3}-0.2 \mathrm{OM} \mathrm{HSA}$ (HSA $/ \mathrm{NH}_{2} \mathrm{OH}=0.75$ ) and (2) $8.27 \mathrm{M}$ $\mathrm{NH}_{2} \mathrm{OH} \cdot \mathrm{HNO}_{3}-0.133 \mathrm{M} \mathrm{HSA}\left(\mathrm{HS} \overline{\mathrm{A}} / \mathrm{NH}_{2} \mathrm{OH}=0.50\right)$. The results are shown in $^{2}$ Figures 1 and 2 and Table 1 .

In this system, where $\mathrm{NH}_{2} \mathrm{OH} \cdot \mathrm{HNO}_{3}$ is $300 \%$ excess and $\mathrm{HSA}$ is $200 \%$ excess (Figure 1) or HSA ${ }^{2}$ is $135 \%$ excess (Figure 2), the reaction rate of HSA with HNO ranges from 6 to 9 times faster than $\mathrm{NH}_{2} \mathrm{OH} \cdot \mathrm{HNO}_{3}$ at $0.3-0.4 \mathrm{M} \mathrm{HNO}_{3}$ to about 1.8 times more rapid at $3.5 \mathrm{M}$ The reaction rate $\mathrm{lagw}_{4}$ for the $\mathrm{NH}_{2} \mathrm{OH}-\mathrm{HNO}_{2}$ reaction has been found
in previous studies ${ }^{3}$ to be

$$
-\mathrm{d}\left(\mathrm{HNO}_{2}\right) / \mathrm{dt}=\mathrm{k}_{1}\left(\mathrm{HNO}_{2}\right)\left(\mathrm{NH}_{3} \mathrm{OH}^{+}\right)\left(\mathrm{H}^{+}\right)
$$


where $k_{1}$ is the rate constant.
reaction has been determined -7 to be
to be law for the $\mathrm{HSA}-\mathrm{HNO}_{2}$

$$
-\mathrm{d}\left(\mathrm{HNO}_{2}\right) / \mathrm{dt}=\mathrm{k}_{2}\left(\mathrm{HNO}_{2}\right)\left(\mathrm{SO}_{3} \mathrm{NH}_{2}^{-}\right)\left(\mathrm{H}^{+}\right)
$$
where $k_{2}$ is the rate constant. The $\mathrm{N}_{2} / \mathrm{N}_{2} \circ$ ratio (Table 1 ) is the
ratio of reaction 4 to reaction 3 , or

$$
\mathrm{N}_{2} / \mathrm{N}_{2} \mathrm{O}=\mathrm{k}_{2}\left(\mathrm{SO}_{3} \mathrm{NH}_{2}^{-}\right) / \mathrm{k}_{1}\left(\mathrm{NH}_{3} \mathrm{OH}^{+}\right)
$$

From the values of $\mathrm{N}_{2} / \mathrm{N}_{2} \mathrm{O}$ in Table $I$ and the ratio of the reactants, the ratios $\mathrm{k}_{1}^{2} / \mathrm{k}_{2}$ were determined and are shown in Figure 3. The straight ${ }^{1}$ ifhe (Figure 3 ) is the least-squares fit of the $\mathrm{k}_{1} / \mathrm{k}_{2}$ ratio as $\mathrm{k}_{1} / \mathrm{k}_{2}=0.056+0.082\left(\mathrm{H}^{+}\right)$with an average standard erfor of 5\%. These values of $k_{1} / k_{2}$ may be compared to the value of 0.016 reported for the competitive reactions in perchloric acid at $0^{\circ} \mathrm{C}$.

Figures 1, 2, and 3 all demonstrated an apparent increase in $\mathrm{NH}_{2} \mathrm{OH}-\mathrm{HNO}_{2}$ reaction rate relative to the $\mathrm{HSO}_{3} \mathrm{NH}_{2}-\mathrm{HNO}_{2}$ reaction rate as the acidity increases. However, the actual cause of the relative rate increase is the increase in ionic strength, 3 which allows easief approach between the positively charged species $\mathrm{NH}_{3} \mathrm{OH}^{+}$and $\mathrm{H}^{+}$in the $\mathrm{HNO}_{2}-\mathrm{NH}_{2} \mathrm{OH}$ rate law. The rate law for the $\mathrm{HNO}_{2}$-HSA involves the reaction between a positively and negatively chafged species and, thus, is affected only slightly by a change in ionic strength. The ionic strength was varied with the acidity in these experiments to be applicable to SRP processes.

$\mathrm{NH}_{2} \mathrm{OH}$ reacts with $\mathrm{HNO}_{3}$ at acid concentrations above $2 \mathrm{M}$, reaching a maximum rate at $5 \mathrm{M} \mathrm{HNO}_{3} \cdot 9$ This reaction is autocatalytic with a 10-15 segond induction period and is usually complete within 30 seconds. The products of the reaction are $\mathrm{N}_{2} \mathrm{O}$ and $\mathrm{HNO}_{2}$, which is believed to be involved in the reaction mechafism. The induction period represents the time necessary for the HNO, concentration to cause a perceptible reaction. Under the conditions of the experiments reported here, the presence of HSA prevents the autocatalytic increase in $\mathrm{HNO}_{2}$, and the reaction is initiated only when $\mathrm{HNO}_{2}$ is added.

\section{APPLICATION TO PLANT PROCESSES}

SRP has successfully tested the substitution of HAN for a portion of the ferrous sulfamate (FS) reductant in the Purex $1 \mathrm{~B}$ bank and plans further tests with the object of mifimizing the iron and sulfate in the solvent extraction waste. Each $0.01 \mathrm{M}$ reduction of the FS concentration in the Purex 1BX stream represents a savings of $\$ 600 \mathrm{M} / 1000 \mathrm{MTU}$ processed in solid waste processing at, DWPF. The amount of reductant required is determined by the $\mathrm{Fe}^{2+}$ 
required to reduce $\mathrm{Pu}^{4+}$ to $\mathrm{Pu}^{3+}$ and the amount of HSA and HAN necessary to suppress $\mathrm{HNO}_{2}$ oxidation. At $0.07 \mathrm{M}$ Fs and $7 \mathrm{~g} \mathrm{Pu}^{3+}$ in the IBP, $\mathrm{Fe}^{2+}$ is 140 in excess of the stiochiometric amount required. A reduction of $0.01 \mathrm{M}$ Fs corresponds to a reduction of $0.02 \mathrm{M}$ in HSA. If the acid profile of the $1 \mathrm{~B}$ bank averages $1.5 \mathrm{M}$ $\mathrm{HNO}_{3}, \mathrm{k}\left(\mathrm{NH}_{2} \mathrm{OH}\right) / \mathrm{k}$ (HSA) is calculated to be 0.18 and an increase in the ${ }^{3} \mathrm{HAN}$ colcentration by $0.02 / 0.18=0.11 \mathrm{M}$ HAN is required to have the equivalent nitrite suppression. This value would be reduced because of the ionic strength contributed by the $\mathrm{UO}_{2}\left(\mathrm{NO}_{3}\right)_{2}$ in the aqueous phase, but does provide a guide for future plant ${ }^{2}$ ests.

\section{ACKNOWLEDGEMENT}

The author is indebted to $R$. H. Young of ADD for the many gas analyses required in this work.

\section{REFERENCES}

1. A. D. Kelmers and D. Y. Valentine, "Search for Alternate Holding Reductants to stabilize Plutonium(III) Solutions," ORNL/TM 6521, September 1978.

2. D. M. Yost and H. Russell, Jr., Systematic Inorganic Chemistry, Prentice-Hall, New York (1946).

3. G. S. Barney, "The Reaction of Hydroxylamine with Nitrous Acid," ARH-SA-97, June 1971.

4. M. R. Bennett, G. M. Brown, L. Maga, and F. A. Posey, Inorg. Chem. 21, 2461 (1982).

5. J. C. M. Li and D. M. Ritter, J. Am. Chem. Soc. $\underline{75}, 5828$ (1953).

6. M. N. Hughes, J. Chem. Soc. (A) 1967, 902 .

7. P. Biddle and J. H. Miles, J. Inorg. Nucl. Chem. 30, 1291 (1968).

8. J. R. Perrott and G. Stedman, J. Inorg. Nucl. Chem. 39, 325 (1977).

9. J. R. Pembridge and G. Stedman, J. Chem. Soc., Dalton Trans., 1979,1657 .

10. TA 2-977E, "HAN-FS Reductant in Purex 1BX stream." 
Table 1.

Reaction Products: $\mathrm{HSO}_{3} \mathrm{NH}_{2}-\mathrm{NH}_{2} \mathrm{OH} \cdot \mathrm{HNO}_{3}$ versus $\mathrm{HNO}_{2}$

Initial Concentrations, $\mathbf{M}^{\mathbf{a}}$

Run

75

51

71

53

61

70

63

74

76

50

72

52

60

62

73

$$
\text { HNO }_{3}
$$

0.40

0.63

1.00

1.23

2.20

2.23

2.7

3.5

0.30

0.63

0.90

1.23

2.13

2.63

3.50
$\mathrm{HSO}_{3} \mathrm{NH}_{2}$

0.20

0.20

0.20

0.20

0.20

0.20

0.20

0.20

0.135

0.135

0.135

0.135

0.135

0.135

0.135
$\underline{\mathrm{N}}_{2}$

87

87

80

82

70

76

65

86

84

81

71

67

70

63
Gas, :

$\mathrm{N}_{2} \quad \mathrm{~N}_{2}$ O

10

13

13

20

18

30

23

35

14

16

19

29

33

30

37
2.0

$2 \cdot 3$

$\underline{\mathrm{N}}_{2} \angle \mathrm{N}_{2}$ 음

8.8

6.8

6.8

4.0

4.7

2.27

3.3

1.86

6.0

5.2

4.3

2.4

1.7

${ }^{a}$ Initial concentration of $\mathrm{NH}_{2} \mathrm{OH} \cdot \mathrm{HNO}_{3}$ was $0.27 \mathrm{M}$ for all runs. 


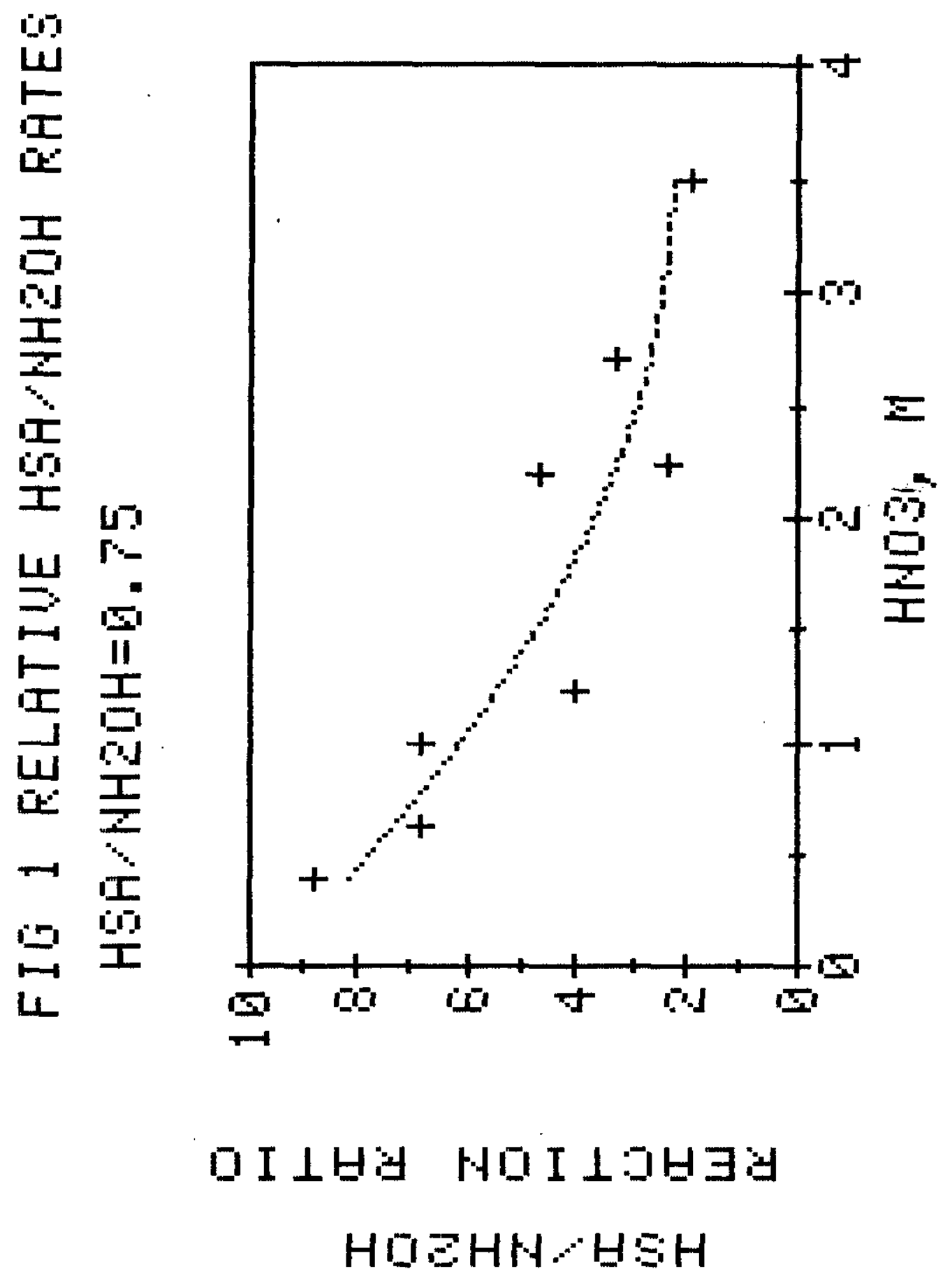




\section{FIG 2 RELATIUE HSA $/ H H Z O H$ RATES}

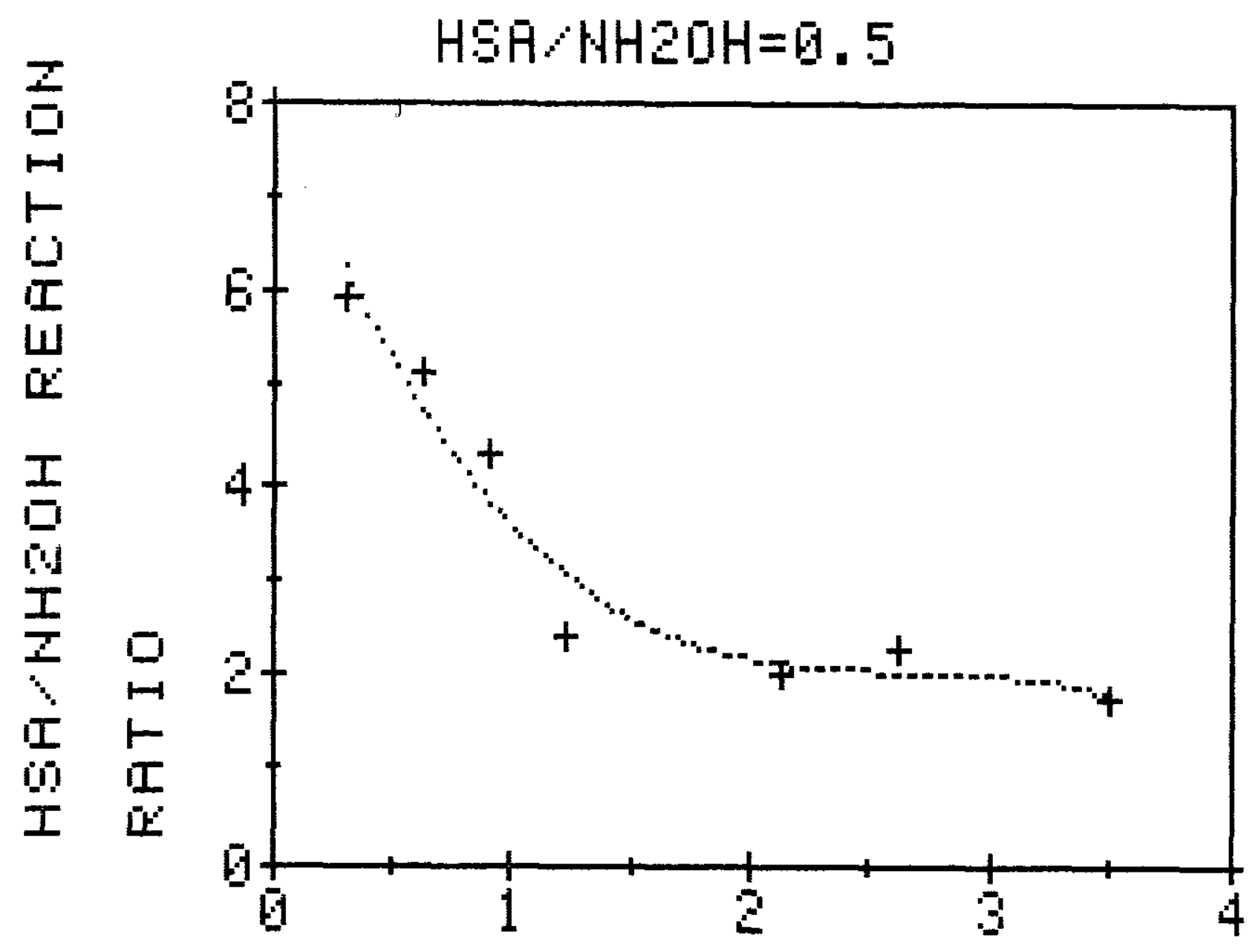

HHOS, H 


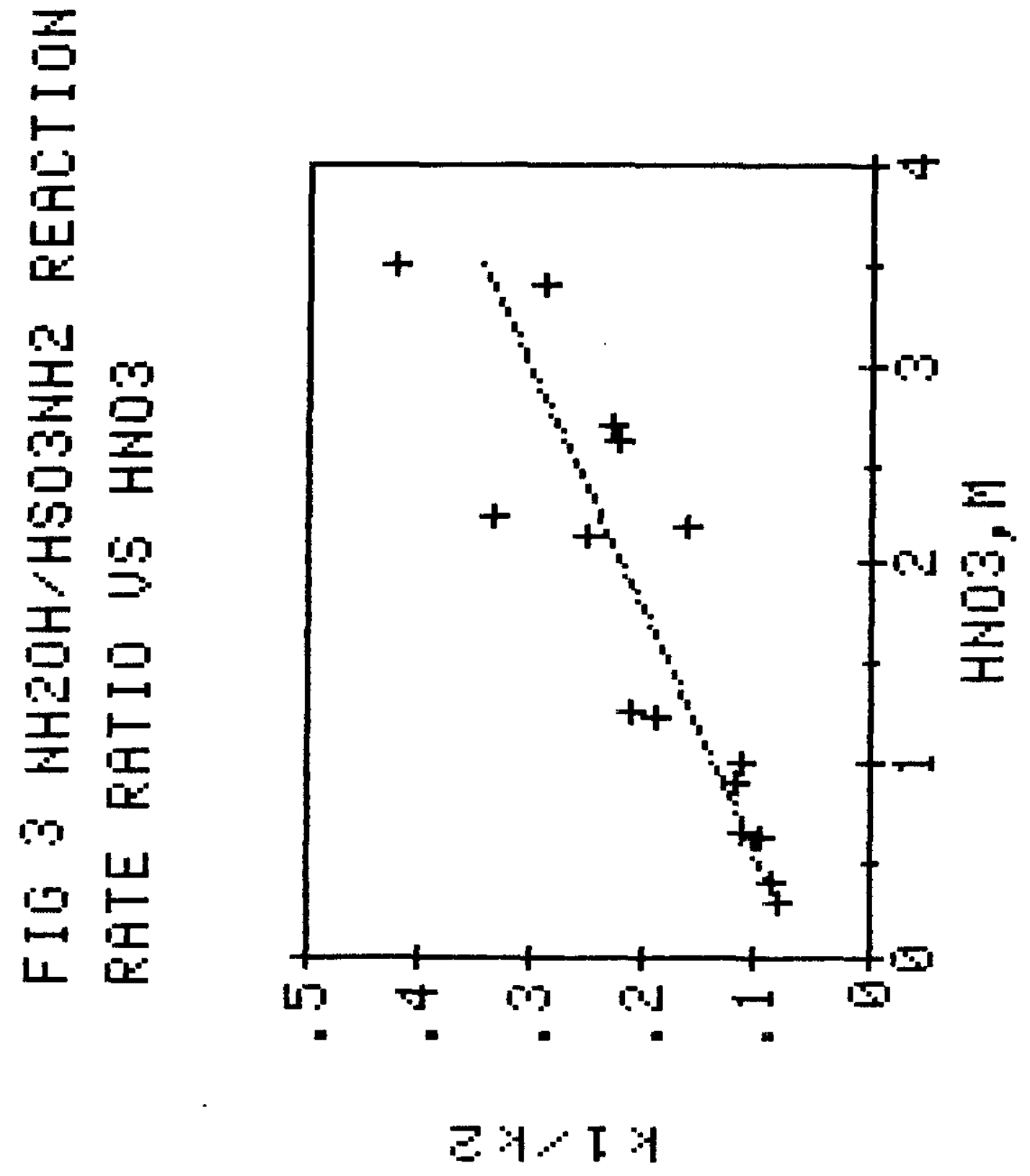

